Den danske regerings antiterrorstrategi strækker sig fra militære midler til dialog; et centralt begreb i regeringens såkaldte "Arabiske Initiativ" til fremme af partnerskaber om "fremskridt og reform" i Mellemøsten. Men hvordan bevarer man kontrollen over dialogens retning? Og hvorfor er det så vigtigt?

\title{
Hvem taler?
}

\section{Hvem lytter?}

DANSKE INVITATIONER TIL DIALOG MOD TERROR

Ulrik Pram Gad er ph.d.-studerende ved Institut for Statskundskab og satsningsområdet "Europa i Forandring" ved Københavns Universitet. Han arbejder på et projekt om danske politikeres skabelse af dansk, europæisk og vestlig identitet i kontrast til muslimer, og var i 2008 gæsteforsker ved NUPI. 
TEKST: Ulrik Pram Gad

Gennem de sidste 5 år er det blevet klart, at vi står midt $i$ en global vordikamp. Det er ikke en vardikamp mellem kulturer eller religioner, det er en vardikamp mellem forstandig oplysning og fundamentalistisk formørkelse, mellem demokrati og diktatur, mellem frihed og tyranni. I den kamp kan man ikke voere neutral ... Den stcerkeste kraft $i$ denne kamp er ønsket om og kravet fra millioner af undertrykte om at få frihed.

I DISSE SATNINGER, centralt placeret $i$ hans «Redegørelse for Rigets tilstand» i 2006, opsummerede den danske statsminister de betingelser, regeringen ser for sin langsigtede antiterrorstrategi: De fleste muslimer venter blot på at blive vore partnere $\mathrm{i}$ det projekt, som vi har for at befri både Os og Dem fra de ekstremister, der truer Os og undertrykker Dem. Som en del af disse partnerskaber spiller dialog en central rolle. Disse projekter for dialog bygger på og er med til at skabe - et bestemt billede af både Os og Dem. For forestillingerne om, hvordan relationen mellem Os og Dem er og bør være, er afgørende for billedet af vores identitet og deres forskel.

Ordet "dialog" stammer fra græsk "dia" ("på tværs af/mellem-") og "logos” (“tale”). Etymologien foreslår altså, at vi taler om en interaktion mellem to eller flere distinkte enheder. I dansk diskurs om kulturmøder bruges ordet dog ofte om en envejsproces; om den ene enheds arbejde for at påvirke den anden. ${ }^{2}$ Også i regeringens beskrivelse af specifikke strategier for terrorforebyggelse betegner ord som "partnerskab" og "dialog" generelt envejstrafik: Vi har noget, som muslimerne behøver (og som de fleste ønsker); partnerskab og dialog er midler til at implementere dette allerede definerede mål.

Denne artikel ${ }^{3}$ analyserer hvordan ordet "dialog" - i den del af den danske regerings antiterrorstrategi, som retter sig mod Mellemøsten - ikke desto mindre gradvist har ændret sig til at omfatte flere indslag af tovejsinteraktion. Ændringen er et resultat af de svar, modparter i Mellemøsten giver på danske dialoginitiativer. Samtidig konstateres et udpræget dansk behov for at kontrollere grænserne for den forskel, der kan indgå i dialogen. De muslimske svar på invitationen til dialog manifesterer sig dermed i dansk diskurs som først en strukturel åbning - umiddelbart fulgt af en lukning overfor input, der kan udfordre dansk selvforståelse.

Først præsenteres artiklens identitetsbegreb ved at forbinde de teoretiske begreber om filosofiske henholdsvis sociologiske Andre - og det skitseres, hvordan partner- 
skabs- og dialogstrategier er blevet italesat som et supplement til mere grundlæggende antiterrorstrategier som eliminering og kontrol. Herefter undersøger artiklen, hvordan ordet "dialog", som det har været brugt i antiterrorpolitikker, kan betegne enten monolog, inklusion eller udveksling mellem to forskellige enheder. Afslutningsvis analyseres det, hvordan et begreb om dialog som tovejs-udveksling afføder et behov for at begrænse den modpart, man inviterer til dialog - i kraft af regeringens behov for at positionere sig som forsvarere af dansk identitet.

\section{Terroristen som radikal Anden}

Man kan ikke udpege nogen som identisk uden at udgrænse andre som forskellige. Men der er aldrig fuldstændig enighed om, hvem der er Os, og hvem der er den ene type Dem og den anden type Dem. Og da vores identitet konstitueres i forhold til Deres forskel, påvirker redefineringen af Dem også Vores identitet.

Filosofisk set er "en radikal Anden" dét, der forhindrer dig i at være den, du burde være. Filosofisk set er der altid endnu en Anden - og endnu en radikal Anden - eftersom identitet som begreb indebærer at enhver forandring, enhver forskel, enhver urenhed kan udpeges som en trussel mod identitet. Og trusler mod identitet vil blive udpeget: Hvis en identitet ikke bliver italesat, er det meningsløst at tale om, at den eksisterer. Så identitet findes kun i diskurs; kun som en del af meningskonstruktion. Men hvorfor skulle man eksplicitere identitet, hvis den er uproblematisk? Hvis en identitet ikke er eksplicit problematisk, findes den ikke - og i det øjeblik, den bringes i eksistens, er den af nødvendighed problematiseret. ${ }^{4}$
Videre: Den radikale Anden - det, der truer og undergraver diskurs - kræver en forklaring: Det truende ægger til at blive diskursiveret og tæmmet. Hvis en specifik gruppe mennesker - en sociologisk Anden - udpeges som dét, der forhindrer én i at være dén, man burde være, så kan man sige, at denne konkrete sociologiske Anden bliver radikaliseret. Eller sagt på en anden måde: Den Anden bliver sikkerhedsliggjort, dvs. udpeget som en sikkerhedstrussel. Den Anden er hermed ikke bare udpeget som anderledes - men som en eksistentiel trussel mod din identitet. ${ }^{5}$

“Terroristen” er en sådan sociologisk Anden, der bliver sikkerhedsliggjort i danske parlamentsdebatter. Terrorister, terrorisme og terrorhandlinger bliver igen og igen eksplicit udpeget som en trussel mod Danmark, danskere og centrale elementer i dansk identitet; ${ }^{6}$ de karakteriseres med en perlerække af invektiver; 7 og de bliver rutinemæssigt fordømt som indgangsbøn til hver partiordførers indlæg. ${ }^{8} \mathrm{Ja}$, regeringen udpeger terror som truslen, der definerer vores sikkerhed:

Det 21. århundredes trusler er fundamentalt anderledes, end dem vi stod overfor under Den Kolde Krig og de første år efter Murens fald. Mareridtet er ikke loengere den altødelocggende atomkrig, men massivt ødelagggende angreb fra globale terrornetvoerk. ${ }^{9}$

Eksistentielle trusler kan man ikke bare sidde overhørig, hvis man har regeringsmagten. Hvis du er i politik, er du nødt til at opretholde din autoritet - og det kræver, at du kan fortælle, hvordan du vil bekæmpe eksistentielle trusler mod den enhed, du repræsenterer. Du må kunne fortælle en plausibel historie om dit valg af strategi. ${ }^{\text {. }}$ 
De umiddelbare reaktioner på angrebene i New York og Washington II. september var i Danmark i 200I-2002 fokuseret på at "bekæmpe terroristerne". Det indebar kontrol- og elimineringsstrategier, både ude og hjemme. ${ }^{\text {II }}$ En strategi for fysisk eliminering af terrorister på deres hjemme-

\section{Eksistentielle trusler kan man ikke bare sidde overhørig, hvis man vil sidde for bordenden. \\ mom}

bane bestod i at slutte sig til USAs aktion i Afghanistan.

Statsministerens udgangspunkt var, som det fremgår ovenfor, at "I den kamp kan man ikke være neutral”. Det er imidlertid kun sjældent, man kan fortælle en historie om en kamp mano a mano mod sin radikale Anden. Som regel er der behov for en mere sofistikeret rollefordeling. ${ }^{\text {I2 }}$ Generelt har man til sådanne historier brug for en længere rolleliste af forskellige knapt-såradikale Andre. ${ }^{\mathrm{I3}}$

Konstruktionen af knapt-så-radikale Andre Som tiden har bragt nye begivenheder til Mellemøsten og europæiske hovedstader er spektret af danske antiterrorstrategier bredt ud - og konstruktionen af de forskellige knapt-så-radikale Andre, som er nødvendige for at udfylde rollerne i stadig mere "bredspektrede" ${ }^{\text {I4 }}$ antiterrorstrategier, er blevet mere kompliceret.

I 2005 - i kølvandet på bombeanslaget i Londons metro 7. juli - forklarede den danske statsminister, at

Vi skal forebygge opbakning og rekruttering til terrorisme gennem vores internationale engagement og gennem en aktiv integrationspolitik herhjemme, [og] vi skal bekcmpe terrorister og terrornetvoerk. ${ }^{15}$

Fra statsministerens og hans ministres indlæg i debatten er det klart, at eliminerings- og kontrolstrategier ("bekæmpe") stadig er centrale. Men relativt forskydes vægtningen - ikke mindst i udenrigspolitikken - til fordel for en "langsigtet" ${ }^{16}$ indsats i form af strategier for omgang med knapt-så-radikale Andre ("forebygge"):

Gennem vores aktive udenrigspolitik søger vi at imødegå de forhold, der ude i verden kan danne grobund for opbakning til terrorisme. ${ }^{17}$

Den aktive udenrigspolitik omfatter blandt andet "fredsbevarende operationer" i form af "genopbygningen af Afghanistan, Irak og Sudan” med det mål at "integrere dem i det internationale samarbejde, herunder samarbejdet om bekæmpelse af terrorisme." ${ }^{\text {8 }}$

De Andre, der er målgruppe for disse antiterrorstrategier, er knapt-så-radikale som terroristerne. Men disse Andre er ikke desto mindre Andre. De kan muligvis inkluderes i et eller andet Vi - men det er ikke en given sag, og det er et åbent spørgsmål, hvilken slags Vi, de kan inkluderes i. De knapt-så-radikale Andre er relativt afsikkerhedsliggjorte sammenlignet med de stærkt sikkerhedsliggjorte radikale Andre men de er så klart fortsat indskrevet $\mathrm{i}$ en sikkerhedsproblematik: ${ }^{\text {19 }}$ Vi har brug for en strategi overfor Dem for at sikre, at de ikke ender som radikalt Andre, det vil si som en eksistentiel trussel mod vores sikkerhed. Vi må genopbygge deres subjektivitet reformere deres identitet og deres handl- 
ingstilbøjeligheder - for at sikre, at de er på vores side.

Der er en lang historie af europæiske og vestlige forsøg på at reformere Andre oftest med henblik på at ligne vores eget forbillede. ${ }^{2 \circ}$ Afhængigt af hvilket kriterium, der opstilles for afgrænsning af identiteten, kan strategierne betegnes konversion (religion), oplysning (viden) eller modernisering (produktionsmåde). Det, der holder disse reformstrategier sammen er, at Vi har et særligt træk, som Vi mener, at De også burde have. Ofte er der nogle af Dem, der er enige - andre gange ikke. Hvilket udløser behov for mere eller mindre hårdhændede taktiske midler til at implementere strategien.

Hvis De konstrueres som splittede mellem, på den ene side Masserne, som er enige $i$ at have behov for at blive mere som os, og på den anden side en gruppe Undertrykkere (massernes radikale Anden), som ikke ser behovet, ${ }^{2 \mathrm{I}}$ så kan en reformstrategi fremstilles som en strategi for befrielse:22

Vi er nødt til at påtage os det ansvar at hjoelpe og sikre, at også den irakiske befolkning får et demokratisk og frit land at leve $i^{23}$

\section{Hvorfor partnerskab og dialog?}

Regeringens eliminerings- og kontrolstrategier suppleres med reform- og befrielsesstrategier. Eliminerings-, kontrol- og reformstrategierne er praktisk taget envejsforehavender: Vi gør noget ved Dem. Hvad De måtte vælge at foretage sig, begrebsliggøres primært som kontraproduktive reaktioner. Befrielsesstrategier er derimod mere overbevisende, hvis der kan konstrueres en Anden, som aktivt tager del i sin egen befrielse. I så fald forvandles befrielsesstrategier til partnerskabsstrategier. ${ }^{24}$
Som tiden går og de umiddelbart valgte eliminerings- og kontrolstrategier er søgt implementeret uden afgørende succes, får partnerskabsstrategier en mere og mere fremtrædende plads i den danske regerings kommunikation. Partnerskaber som antiterrorstrategi forudsætter generelt et

\section{Et begreb om dialog som tovejs- udveksling afføder et behov for at begrcense dialogmodparten.}

fælles mål; et mål defineret af den part, der artikulerer partnerskabet. Enten fordi initiativtageren ekspliciterer det mål, partneren må indvillige i at sigte på, eller fordi initiativtageren inkarnerer en egenskab som partneren - ved at indgå i partnerskabet implicit sigter på at opnå. Hovedparten af de specifikke partnerskabsstrategier forbliver således indenfor en grundlæggende asymmetrisk reformlogik. Af og til forekommer det ikke desto mindre, at ordet "dialog" indebærer en mindre skæv relation mellem Selv og Anden.

I en debat i 2005 - i skyggen af bomberne i London 7. juli - beskrev statsministeren særligt et udenrigspolitisk tiltag som fokuseret på partnerskaber mellem danske aktører og visse muslimske Andre:

[V]i [har] med Det Arabiske Initiativ startet en vigtig dialog med de arabiske lande... Initiativet støtter lokale reformer $i$ retning af mere frie og demokratiske samfund, en udvikling, som regeringen finder afgørende i forebyggelsen af yderligere radikalisering. ${ }^{25}$

Spektret af konkrete dialogaktiviteter 
strakte sig fra samarbejde om udvikling af en jordansk ombudsmandsinstitution over støtte til marokkanske kvindeorganisationer til udveksling mellem danske og arabiske ungdomsorganisationer. ${ }^{26}$ Elementer af Det Arabiske Initiativ indgik senere i det forslag til handlingsplan mod radikalisering, som Integrationsministeriet sendte $i$ høring i 2008. ${ }^{27}$ Efter London-bomberne er fokus her på "hjemmegroede" terrorister og dermed på integrationspolitikken - men eftersom muslimske unge i Danmark påvirkes fra Mellemøsten, inddrages Det Arabiske Initiativ også i denne sammenhæng.

I handlingsplanen gives to grunde til at partnerskaber og dialog er nødvendige strategier. Den første grund er, at Vi - Danmark - har behov for partnere, hvis vi skal kunne kommunikere til potentielt radikaliserede muslimer (i Danmark såvel som i Mellemøsten). Vi behøver ikke-radikaliserede muslimer til at kommunikere til potentielt-radikaliserede muslimer fordi

når det gaelder om at bearbejde holdninger og normer hos en person, der har uafklarede identitetsspørgsmål, eller som allerede er praget af fastgroede ekstremistiske toenkemåder, er den dialog, som foregår ansigt til ansigt helt central. ${ }^{28}$

Derfor kan der "være behov for en øget inddragelse af den danske ressourcebase med rødder i disse regioner", ${ }^{29}$ hvorfor Udenrigsministeriet vil

udsende en arabisktalende medarbejder til en af ambassaderne $i$ den arabiske verden, der blandt andet vil ... sikre formidling af de positive historier om Danmark til den arabiske/muslimske verden..$^{\circ}$
Den anden grund til at vælge en dialogstrategi er, at eksklusion (også i form af subjektivt opfattet eksklusion og selv-eksklusion) er "en trussel mod sammenhængskraften”. ${ }^{\text {I }}$ For

Mistankeliggørelse af etniske eller religiøse grupper kan bruges aktivt $i$ den propaganda, som vi ser fra dem, der er modstandere af et mangfoldigt demokratisk samfund..$^{32}$

Så Vi må aktivt inkludere Muslimer for at undgå deres selvradikaliserende eksklusion.

Det ligger imidlertid ikke lige for, hvordan man inkluderer skeptikere og selvekskluderede. Ydermere legitimerer disse to grunde ikke et fuldstændigt skifte til strategier for ukontrolleret tovejsdialog.

For det første peger regeringens behov for at opfinde begrebet "uenig dialog"33 på nødvendigheden af nøje opmærksomhed på, hvordan ordet "dialog” bruges. I det følgende zoomer artiklen således ind på dialog som monolog; dialog som inklusion; og endelig dialog som udveksling med behov for en modpart.

For det andet er der stadig grænser, der må holdes under kontrol. Dette er i fokus for den afsluttende del af artiklen, som viser, hvordan regeringens positionering som forsvarer for dansk identitet giver behov for overvågning af den Andens forskel.

\section{Dialog som monolog}

Først og fremmest ledsages ordet "dialog" i regeringens tekster om terrorforebyggelse ofte af ordet "oplysning" 34 - og selvom en overskrift siger "dialog", kan indholdet være “oplysning”. Et eksempel er den beskrivelse, handlingsplanen mod radikali- 
sering giver af hovedindholdet i Det Arabiske Initiativ: "en præcis og nuanceret oplysningsindsats", "public diplomacy initiativer om dansk udenrigspolitik", "udfordre og modgå den entydige og negative fremstilling af dansk udenrigspolitisk engagement", "informationsmøder, "informationsmaterialer"; alle envejstiltag under overskriften "dialog og oplysning". ${ }^{35}$ I disse tilfælde er "dialog" egentlig en monolog.

En envejs-informationsstrategi ledsages ofte af en analyse af fordelingen af viden, som placerer Sandheden hos Os - hvorimod De tager Fejl:

[Karikatur]tegningesagen har ... vist, at arabiske befolkninger har et alt for ringe kendskab til vores samfund og ikke mindst vores store indsats og engagement $i$ regionen. ${ }^{36}$

Virkningen af denne rollefordeling er, at dagsordenen for dialogen begrænses: regeringens primære strategi for terrorbekæmpelse - eliminering og kontrol via deltagelse i krigene i Afghanistan og Irak isoleres fra kritik fra Mellemøsten. På dette område er der ikke brug for input fra Dem; kun for oplysning fra Os. Dialog-sommonolog indebærer en praktisk udsættelse af tovejs-udveksling: $\mathrm{Nu}$ lytter $\mathrm{Du}$ og gør som Vi siger - senere kan det være, at du bliver klar til at tale på en måde, det er værd at lytte til. Dette budskab, indeholdt i dialog-som-monolog, harmonerer ikke særligt godt med de strategier for dialog-sominklusion og dialog-som-udveksling, som også findes i regeringens palet.

\section{Dialog som inklusion}

Inklusion af ikke-radikaliserede muslimer er et centralt element $i$ den danske reger- ings antiterrorstrategier. For at der er nogen, der vil modtage invitationerne til inklusion, er det imidlertid afgørende, at de ikke føler sig patroniserede:

Når det galder arbejdet $i$ den muslimske verden er det sarlig vigtigt, at indsatsen ikke opfattes som "kulturel imperialisme" og at den ikke får et skar af religiøs missionsvirksomhed. ${ }^{37}$

Der skal altså findes ikke-autoritære og ikke-tvangsmæssige måder at formulere invitationer til Dem om frit at engagere sig i det projekt, der retter sig mod Deres egen befrielse.

Her ses selve dialogprocessen som en inklusionsmekanisme - ikke bare til inklusion $i$ et fællesskab om praktisk interaktion, men også inklusion i det værdisæt, som indrammer partnerskabet:

Regeringens overordnede mål ... er at støtte reformer og fremskridt $i$ de arabiske lande ... og at fremme den politiske dialog mellem parter $i$ disse lande og Danmark.1 Disse to formål anses som to sider af samme mønt ... Det betyder blandt andet helt konkret, at langt de fleste aktiviteter under programmet vil blive udviklet og udfoldet $i$ partnerskaber mellem danske og arabiske organisationer ... Det medfører en naturlig dialog om reformspørgsmål. $3^{8}$

Så ordet "dialog" kan betyde en invitation til inklusion gennem at opleve deltagelse; en invitation, som det er en følsom opgave at formulere, eftersom den hierarkiske relation - som ligger $i$, at det er Os, der leverer mål, betingelser og ressourcer for forholdet - ikke må være for tydelig.

Anders Fogh Rasmussen, Danmarks statsminister. 


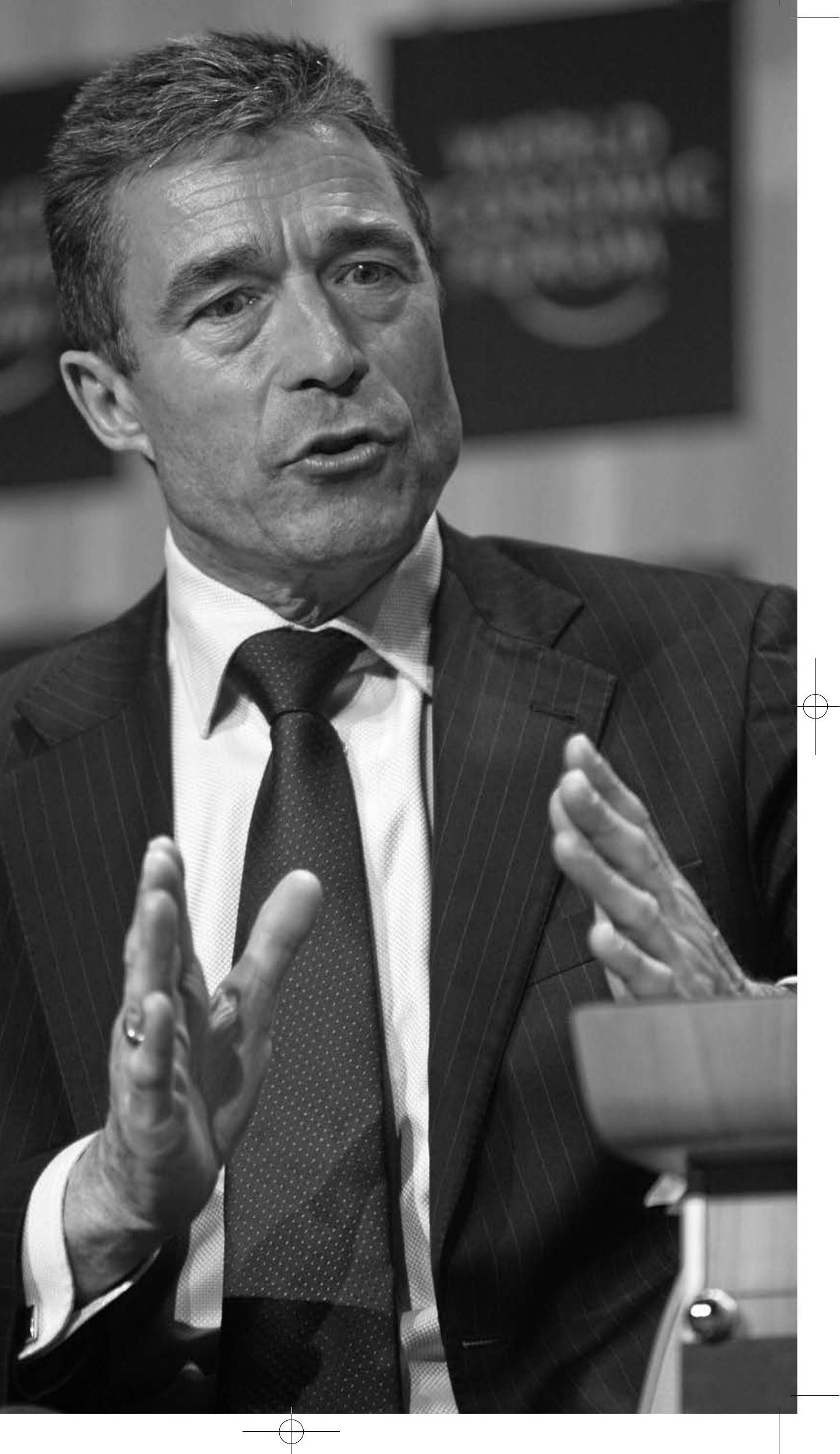




\section{Dialog som udveksling}

Som udgangspunkt er den foretrukne form for dialog envejs: Vi taler - De lytter. Men Det Arabiske Initiativ indeholder også en anden type dialogprojekter:

[D]e egentlige dialog-projekter skal bryde meningsmodsatninger og skabe kontakt på tvoers af skel, der ellers ikke nødvendigvis var blevet passeret. ${ }^{39}$

Denne "egentlige dialog" udgøres af tovejsudveksling mellem forskellige enheder. Dialog som tovejs-udveksling indebærer, at det er nødvendigt for Os at lytte til, hvad De har at sige.

For reaktionerne fra Danmarks potentielle og faktiske muslimske dialogparter i Mellemøsten gør det vanskeligere at undgå, at dialogen bliver tovejs, hvis den skal finde sted overhovedet. I evalueringen af Det Arabiske Initiativ beskriver Udenrigsministeriet

den egentlige hensigt med en dialog [som]: gensidig erfaringsudveksling og udvidet horisont på begge sider. ${ }^{\circ}$

Altså en tovejs-udveksling mellem forskellige enheder. Det interessante er, at denne definition kun optræder en passant som retfærdiggørelse af det uforudsete behov for danske NGO'ers selv-udvikling som en del af processen med at etablere partnerskaber:

mange af de danske organisationer har skullet loere og drage egne erfaringer under samarbejdet med deres arabiske partnere. ${ }^{41}$

Udenrigsministeriet resumerer parallelt resultaterne af en undersøgelse af arabiske opfattelser af Danmark i kølvandet på karikaturkrisen og finder et

udtrykt ønske om dialog, hvor der er en oegte gensidighed ... hvor begge parter $i$ udgangspunktet anerkender eksistensen af forskelle samt udviser en vilje til også at forholde sig til problemerne $i$ ens eget samfund..$^{2}$

Disse to citater kan illustrere to pointer: For det første er de eksemplariske ved, at den væsentligste erfaring, der tages med ud af dialogen, er bekræftelsen af forskellen. Der tages ingen substantiel inspiration med fra den Andens måde at tænke eller gøre tingene på. Og den væsentligste lære, der drages af forsøget på dialog er, at den Anden

\section{Hvis man inviterer nogen til en}

dialog, risikerer man, at de krover, at det bliver en tovejs-udveksling.

mener sig ligeværdig. En ligeværdighed, der strukturelt passer dårligt ind i et målrettet partnerskab om at nå Vores mål.

For det andet understreger de to passager den styrke, der ligger i selve ordet "dialog": Hvis man inviterer nogen til en dialog, risikerer man at de kræver, at det bliver en tovejs-udveksling. Og hvis man involverer sig i en tovejs-udveksling - ved ikke bare at tale, men også lytte - risikerer man at møde et krav om, at man reformerer sig selv. Selvom målet med din invitation oprindeligt var at den Anden skulle reformeres.

Det er i første omgang denne lære, handlingsplanen til forebyggelse af radikalisering drager konsekvensen af med 
begrebet "uenig dialog" som beskrivelse af en strategi for tovejs-dialog mellem uenige partnere:

I et vist omfang skal der også satses på "uenig dialog" - det vil sige direkte dialog med personer, der reprosenterer kontroversielle holdninger, men som har muligheder for at holdningspåvirke de unge $i$ en fredelig og ansvarlig retning. ${ }^{43}$

For at opsummere: Som en antiterrorstrategi foreslår regeringen at invitere ikkeradikaliserede muslimer til dialog. Efterhånden som den Anden tager imod - eller undlader at tage imod - invitationen, formulerer regeringen et begreb om dialog som en tovejs-proces; det vil si en proces der indebærer at også Vi lytter. Så langt så godt. Den substantielle lære, der drages af modpartens reaktion på dialogforsøgene, er imidlertid dels en bekræftelse af den Andens forskel; dels det foruroligende, at den Anden mener sig ligeværdig. Hvis disse svar ikke skal udfordre Vores selvbillede, må modpartens forskel holdes indenfor visse grænser.

\section{Bevar kontrollen; grænser for forskel}

At invitere en Anden til dialog forstået som monolog er i første omgang en selvbeskyttende strategi; det værste, der kan ske, er at den Anden ikke lytter og ikke reformerer sig selv. ${ }^{44}$ Inviterer man en anden til dialog forstået som inklusion eller tovejs-interaktion, har man umiddelbart mere på spil, eftersom man allerede har tildelt den Anden en platform at tale fra: Man har selv forhånds-legitimeret den Andens interventioner. Så stillet overfor en tovejsdialog opstår behov for at afgrænse den forskel, som den Anden tager med ind i dialogen. Det er en forudsætning for at bevare kontrollen over dialogen - og dermed over sin egen identitet.

Deltagerkredsen søges afgrænset ved igen og igen at påkalde sig en liste af abstrakte begreber med en tung bagage af liberal, vestlig politisk filosofi:

Dialogen må bygge på gensidig respekt. Kulturelle og religiøse forskelle skal anerkendes inden for rammerne af de universelle menneskerettigheder ... Hvor ekstremisme ... stiller sig $i$ vejen for demokrati og respekt for menneskerettighederne, skal Danmark aktivt støtte de krofter, der arbejder for tolerance og respekt for det enkelte menneske.45

Sammenlignet med de principielle udsagn i regeringsteksterne, opstiller den parlamentariske debat endnu et krav. Med en ordfører for det liberale regeringspartis ord:

[I]nitiativet [skal] koncentreres omkring de samarbejdsvillige lande og regeringer ... Vi skal stille krav om demokratisering og reformvilje. ${ }^{46}$

Efter turen omkring Folketinget udstrækkes initiativets invitation således kun til de, der allerede siges at have en track record af selv-reform - og ikke alle dem, der blot måtte erklære deres tilslutning til listen af adgangskriterier.

\section{Dialog som vedhæng til selv-realisering}

Regeringen artikulerer strategier for tovejsdialog - for straks at begrænse omfanget af den forskel, der kan tillades i dialogen. Denne artikulation er en del af regeringens fremstilling af sig selv som forsvarere for dansk identitet i kraft af reformen af den Anden - imellem på den ene side rege- 
ringens nationalistiske støtteparti, Dansk Folkeparti (DF), som betvivler, at det skulle være muligt at reformere den Anden, og på den anden side en opposition, som taler for selv-reform.

DF sætter igen og igen spørgsmålstegn ved, om muslimer overhovedet kan reformeres og inkluderes; om de er i stand til demokrati.47 For at understøtte, at dialog med det formål at reformere den muslimske verden er en ansvarlig antiterrorstrategi, arbejder regeringen heroverfor for at gentegne billedet af en vestlig civilisation, som clasher med en muslimsk. Det clash, der skal stå tilbage, er mellem civilisation (i Vesten og i den muslimske verden) på den ene side og fundamentalisme på den anden:

Det civilisationernes sammenstød, som mange frygter vil ødeloegge en rolig verdensudvikling $i$ fremtiden, finder nu sted inde $i$ de muslimske civilisationer, hvor fundamentalisterne vil skade de mange gode krafter $i$ den arabiske verden, der ligesom vi ser det som afgørende at få Mellemøsten konstruktivt med $i$ globaliseringsprocessen, og som søger stabilitet, sikkerhed og fremgang, og som også ser det som afgørende at få åbnet landene politisk og økonomisk og dermed bidrage til at svokke islamismen og stoppe terrorismen, der ødeloegger deres hverdag. $4^{8}$

Men dette gentegnede clash tages af oppositionen som et oplæg til at forlænge frontlinjerne, således at regeringens støtteparti ekskluderes fra det Vi, der udgøres af "civilisationen", og forvises til dens ekstremistiske ydre som radikalt Anden. Denne påståede strategi af gensidig afhængighed mellem civilisationsclashere kan endda fremstilles som en art "dialog":
Dansk Folkeparti og de politiske islamister, vi ser i Mellemøsten ... noerer hinanden og lever af hinanden og skaber en konfrontatorisk dialog, som ... skader andre menneskers forsøg ... på at skabe dialog og mellemfolkelig forståelse. ${ }^{49}$

Så for oppositionen står kampen mellem to dialogrelationer med hvert sit sæt af roller: En "konfrontatorisk dialog" mellem to på overfladen radikale modstandere - som i virkeligheden gør fælles sag mod og dermed tilsammen udgør den radikale Anden for "dialog og forståelse" mellem os og muslimske knapt-så-radikale Andre.

Men i dette alternativ bliver "dialog" et vedhæng til "forståelse" - og forståelsens substans er allerede forudetableret: De spørgsmål, der stilles til den Anden i dialogen, bliver retoriske - og tilsvarende er de svar, den Anden skal levere i dialogen, kendte allerede før dialogen indledes. Sådan må det være, hvis konklusionen - at Vi må begive os ud i selv-reform - er kendt fra begyndelsen. Vi kan kun gøre os håb om at påvirke den Anden til at reformere sig selv, hvis vi går foran med et eksempel til efterfølgelse:

Hvis vores budskab om demokratisering og respekt for menneskerettighederne skal have nogen effekt, er det nødvendigt, at vi selv lever op til disse standarder, og det gør Danmark desvorre ikke..$^{\circ}$

Denne form for dialog-som-anticiperetpost-scriptum-til-selv-reform opretholder imidlertid en strukturel åbenhed overfor den Anden. Selvom Vi i første omgang ikke har ventet på egentligt at lytte, er det svært at afslå at høre efter, hvis dialog-partneren skulle give sig til at sige noget. 
Sådan er situationen ikke, hvis du ser dig selv som bærende på egenskaber, der må beskyttes mod forandring: Så indebærer enhver åbenhed mod den Anden en risiko for din identitet - selv hvis den Anden, vi inviterer i dialog, ikke som udgangspunkt er beskrevet som en radikal Anden. For hvis den knapt-så-radikale Anden gentager den radikale Andens krav, er resultatet det samme:

[T]erroren har vundet, hvis [vi] ikke er villige til at gøre det, der skal gøres, når terrorismen og terrornetvorkene krover det? Er [det oerede medlem] virkelig villig til at give efter for terrorismen og lade terrortruslen betyde, at man afstår fra at gøre noget..$^{51}$

Med denne argumentation er det ikke blot denne eller hin egenskab ved Os, der sættes spørgsmålstegn ved; det er selve Vores handlingsformåen, der er på spil: Hvis vi lytter til de mulige krav fra Dem og afviger fra denne kurs, vil vi have mistet vores handlingsformåen i det hele taget - eftersom dette krav også optræder på den radikale Andens liste.

I denne situation må dialog begrænses til at være et vedhæng til en anden form for selv-realisering: ikke selv-reform men selvforskansning:

Vi ønsker ... ikke et multikulturelt Danmark ... $V i$ skal blive meget bedre til dialogen med andre kulturer og religioner og $i$ den dialog turde sige, hvem vi selv er, og efter hvilke voerdier vi har indrettet samfundet. Tilstedevorelsen af mennesker med anden etnisk baggrund og anden religiøs tro skal ikke få os til at opgive vort eget..$^{2}$
En indre dialog - som potentielt sætter identiteten på spil - må afværges; prisen er, at en ydre tovejs-dialog med den Anden er for farlig, eftersom den kunne så tvivl om identitetens nødvendighed. Den knapt-såradikale Anden er faktisk radikal.

Og eftersom regeringen ikke er til sinds at sætte spørgsmålstegn ved sine grundlæggende eliminerings-, kontrol- og befrielsesstrategier, må der være kontrol med, hvad resultatet af dialogen kan blive. Det kræver, at grænserne for dialogpartnerens forskellighed nøje overvåges. Overvågningen af de knapt-så-radikale Andre kommer som et direkte svar til DF, som regeringen er afhængig af for sit parlamentariske flertal:

$[M] e d$ hensyn til de indvandrere, der skal deltage og medvirke $i$ det her projekt [Det Arabiske Initiativ]: Hvordan sikrer vi nu, at de folk, som vi samarbejder med her, der har en forbindelse til Mellemøsten, og som bor i Danmark og måske oven $i$ købet er danske statsborgere, ikke er identiske med de imamer, som $i$ høj grad ødelagde det for Danmark [under karikaturkrisen]?53

Overvågningstiltagene er helt konkrete, særligt i den del af handlingsplanen mod radikalisering, som beskæftiger sig med integrationspolitik.

\section{Behovet for identitet overfor dialog}

Den danske regering fremstiller dialog med en knapt-så-radikal muslimsk Anden som en nødvendig del af et nødvendigt forsvar mod terror. Fra Mellemøsten mødes invitationen til dialog med en insisteren på, at dialog ikke kan være en envejs-affære. Men når dialog indebærer, at også Vi skal lytte, opstår behovet for at begrænse og 
overvåge den Andens forskel, som accepteres til at indgå i en tovejs-dialog: Ellers kan resultatet være, at Vores identitet og selvforståelse kompromitteres af de krav, vi får at høre. Resultatet bliver en dialog, der ikke er entydigt envejs - men hvor man anstrenger sig for kun at høre de svar, der bekræfter ens egne replikker. En art mono$\log$ i stereo.

\section{$\cdot f \cdot$}

I Statsminister Anders Fogh Rasmussen, Venstre, Folketingets forhandlinger, åbningstalen (RI), 2006.I0.03 I2:05. I det følgende har referencer til Folketingsets forhandlinger, tilgængelig via www.ft.dk, denne form: Titel efternavn, partitilhør, dagsordenspunkt, åååå.mm.dd tt:mm.

2 Lindekilde, Lasse: "Claim-making of Danish Muslims during the Muhammed Caricatures Controversy: A Challenge to the Principles of the Secular Public Sphere?", paper til konferencen Secularism and Beyond - Comparative Perspectives, Københavns Universitet, 3I. maj- 2. juni, 2006, s.4f, cf. s. 20.

3 Denne artikel udspringer af en analyse, der sammenholder dialogbegreber $\mathrm{i}$ relation til muslimer i dansk integrations- og mellemøstpolitik. En foreløbig udgave af denne analyse - med yderligere referencer og en komplet liste over det analyserede materiale - findes i Gad, Ulrik Pram: "It takes two to Tango. Danish concepts of dialogue as counterterrorism", NUPI Working Paper, Nr. 747, 2008. Mine tanker om problemstillingen er hjulpet på vej af drøftelser ved seminarer i regi af Terrorforskningskonsortiet/NUPI, Sikkerhedsprogrammet på PRIO og Institut for Statskundskab ved Universitetet i Oslo.

4 Wæver, Ole: «Concepts of Security», Ph.d. thesis, Copen hagen: Department of Political Science, 1997, s.328-9. Zizek, Slavoj: "Eastern Republics of Gilead", kap. 9 i Mouffe, Chantal (ed.): «Dimensions of Radical Democracy», London: Verso, I992, S.I97. Derrida, Jacques: "Différance", i «Margins of Philosophy», University of Chicago Press, 1982, S.I-28.

5 Connolly, William E.: «Identity|Difference. Democratic Negotiations of Political Paradox», Ithaca: Cornell University Press, I99I, s. 8, 64 .

6 "For Danmarks vedkommende er terrorismen en trussel mod samfundet og de værdier, som det bygger på, og mod den enkelte borger." (Justitsminister Espersen, kons., L2I7, 2006.03.3I, skriftlig fremsættelse). "De terrorister, vi kender i dag, ønsker at bekæmpe demokratiet og retssikkerheden." (MF Barfod, Enhedslisten, F7, 2005.II.I6 I8.20).

7 "[F]remtidens trussel nr. I" (MF Poulsen, Venstre, ADi4, 2004.03.I7 I2:IO); "modbydelige" (MF Poulsen, Venstre, ADi4, I2:I0, MF Jensen, soc.dem., ADi4, I2:I0; MF Messerschmidt, Dansk Folkeparti, FI, 2005.04.06 I6:25; I7:00); "brutal" (MF Poulsen, Venstre, ADI4, I2:I0); "ondskab" (MF Jensen, soc.dem., ADı4, I2:I0); "bestialsk" (MF Behnke, kons., F7, 2005.II.06 I7.25-30); "vanvittige" (MF Barfod, Enhedslisten, F7, I8:20).

8 "[I]ntet kan jo undskylde eller legitimere terror" (MF Baastrup, SF, F7, 2005.II.06 I8:I0) ; "Terror er altid en uforsvarlig handling og en handling, der altid må fordømmes." (MF Hoydal, Færøerne, F7, I8.30); "Ethvert anstændigt menneske fordømmer terrorisme." (MF ArboBæhr, Enhedslisten, RI, 2005.I0.06 I7:35).

9 Regeringen: «En verden i forandring», 2003, S.2.

Io Wæver, Ole: "Securitization and Desecuritization", kap.3 i Lipschutz, Ronnie D. (ed.): «On Security», New York: Columbia University Press, I995.

II Cf. Todorov, Tzvetan: «The Conquest of America. The Question of the Other», New York: Harper \& Row, I984. Lindqvist, Sven: «Utrota varenda jävel», Stockholm: Bonnier, I992. Foucault, Michel: «Discipline and Punish. The Birth of the Prison», New York: Pantheon, 1978.

I2 Cf. Hansen, Lene: «Security as Practice», London: Routledge, 2006 , s.40.

I3 Hansen, Lene: «Western Vilains or Balkan Barbarism?», Ph.d. thesis, Copenhagen: Department of Political Science, I998.

I4 Ministeriet for Flygtninge, Indvandrere og Integration: «En fælles og tryg fremtid - forslag til en handlingsplan om forebyggelse af ekstremistiske holdninger og radikalisering blandt unge», København, høringsudgave, juni 2008, s. 29. Cf. Pedersen, Karen L.: «Terrorism: Corporate Risk and National Security (Re)Stated», Ph.d. dissertation, Department of Political Science, University of Copenhagen, 2008.

I5 Statsminister Rasmussen, F7, 2005.II.I6 I5:I5, cf. Regeringen, 2003 , S. I3.

I6 Statsminister Rasmussen, F7, 2005.II.I6 I5:I5.

I7 Statsminister Rasmussen, F7, 2005.II.I6 I5:I5, kursiv tilføjet.

I8 Statsminister Rasmussen, F7, 2005.II.I6 I5:I5.

I9 Cf. Wæver, Ole: "Insecurity, Security and Asecurity in the West European Non-War Community”, s.69-II8 i Adler, Emanuel \& Barnett, Michael (eds.): «Security Communities», Cambridge UP, 1998.

20 Cf. Todorov I984.

2I Cf. Hansen 2006, S.II4.

22 Cf. Laclau, Ernesto: «Emancipation(s)», London: Verso, 1996. Laclau, Ernesto: «On Populist Reason», London: Verso, 2006.

23 MF Behnke, kons., F7, 2005.II.I6 I7:40; cf. statsminister Rasmussen, Venstre, RI, 2003.I0.07 I2:30.

24 Andersen, Niels Åkerstrøm : «Partnerships. Machines of possibility», Bristol: Policy Press, 2008, s. 42ff, Io6.

25 Statsminister Rasmussen, Venstre, F7, 2005.II.I6, I5:I5. Det Arabiske Initiativ blev oprindeligt formuleret i 2003 
som en del af et omfattende udenrigspolitisk policydokument (Regeringen 2003), men blev først lanceret offentligt med Udenrigsministeriet: «Det Arabiske Initiativ», 2005. Initiativet blev evalueret og tilpasset i 2006 i kølvandet på "karrikaturkrisen", som fulgte JyllandsPostens offentliggørelse af I2 tegninger, man havde bestilt af profeten Muhammed, se Udenrigsministeriet: «Analyse af det arabiske initiativ og anbefalinger til næste fase», 2006. Folketinget debatterede initiativet og evalueringen den 24. maj 2006 ved forespørgselsdebat F45, til gængelig via www.ft.dk.

26 For en oversigt over alle aktiviteter i de første faser af initiativet, se Udenrigsministeriet 2006, s. $29 \mathrm{ff}$.

27 Ministeriet 2008.

28 Ministeriet 2008, s.30.

29 Ministeriet 2008, S.Io.

30 Ministeriet 2008, s.37.

3I Ministeriet 2008, S.IO, cf. s.IIff.

32 Ministeriet 2008, s.I3.

33 Ministeriet 2008, s. 34 .

34 Ministeriet 2008, s.34, 35, 37.

35 Ministeriet 2008, s.35

36 MF Poulsen, Venstre , F45, 2006.05.24 I6:45; cf. Ministeriet 2008, s.57; MF Christmas-Møller, kons., F45, I7:30.

37 Regeringen 2003, s.I6.

38 Udenrigsministeriet 2005, s. 7, 9. To konkrete eksempler er dels udveksling af studerende og curricula samt forskningssamarbejde mellem universiteter, dels co-produktion og udveksling mellem journalister (Udenrigsministeriet 2006, s.23).

39 Udenrigsministeriet 2005, s.9.

40 Udenrigsministeriet 2006, s.Io, kursiv tilføjet.

4I Udenrigsministeriet, 2006, s.Io. To konkrete eksempler er udveksling af studenter og curricula samt forskningssamarbejde mellem universiteter og co-produktion og udveksling mellem journalister (Udenrigsministeriet 2006, s.23).

42 Udenrigsministeriet, 2006, S.I3.

43 Ministeriet 2008, s.34.

44 Cf. dog Rumelili, Bahar: "Constructing identity and relating to difference: understanding the EU's mode of differentiation", i Review of International Studies, Vol.30, nr.I, s.27-47; Gad, Ulrik Pram: Anmeldelse af Rumelili, B.: «Constructing Regional Community and Order in Europe and Southeast Asia». Palgrave Macmillan, i Tidsskriftet Politik, 2008, vol.II, nr.2.

45 Regeringen 2003 , S. I4.

46 MF Poulsen, Venstre, F45, I6:45.
47 MF Espersen, DF, F45, I7:Io; cf. MF Langballe, DF, in Pedersen, K. H.: "Har islam indbygget terror?", interview med Jesper Langballe (MF, DF) og Jørgen Bæk Simonsen (professor, islamolog, Københavns Universitet), i Universitetsavisen, 2006, nr.I7, s.8-II.

48 Udenrigsminister Møller, kons., F45, I6:30; cf. MF Kofod, soc.dem, F45, i7:05.

49 MF Lund, Enhedslisten, F45, I7:55; cf. MF Søvndal, SF, F45, I7:I5; MF Kofod, soc.dem., F45, I7:I5; MF Lund, Enhedslisten, F45, I7:25.

50 MF Lund, Enhedslisten, F45, 2006.05.24, I7:45; cf. MF Helveg Pedersen, Radikale Venstre, F45, 2006.05.24, I8:00; MF Søvndal, SF, F45, I7:35-40; MF Baastrup, SF, F7, I8:I0-15.

5I MF Poulsen, Venstre, ADI4, I2:40; cf. MF Langballe, DF, USio8; Udenrigsminister Møller, kons., USio8; MF Langballe, DF, F7, I7:40-45; MF Espersen, DF, F7, I9:IO.

$52 \mathrm{MF}$ - og senere integrationsminister - Hornbech, Venstre, FI8, 2000.II.23.

53 MF Espersen, DF, F45, I8.25.

54 Gad, op.cit. n.3, 2008, afsnit 8. 